\title{
Low-carbon Tourism Traffic Behavior Research: The Case of the Residents in Wuhan
}

\author{
Chun Liu', 2 \\ ${ }^{1}$ Wuhan Technology and Business University, Department of Management, Wuhan 430065, China \\ ${ }^{2}$ Hubei Business Service Development Research Center, Wuhan 430065, China \\ Ic576@126.com
}

Keywords: Low-carbon tourism, Low-carbon traffic, Variance analysis.

\begin{abstract}
This paper, Wuhan residents as the research object, establishes variable system of influencing low-carbon tourism traffic behavior intentions, constructs influence factor model of low-carbon tourism traffic behavior intention. By descriptive analysis, reliability analysis, factor analysis, correlation analysis and variance analysis, verify the relationship and significantly effect between the variables and low-carbon tourism traffic behavior intention. The analysis results based on survey data show that: (1) low-carbon tourism traffic behavior attitude, subjective norm, perceived behavior control have the biggest positive impact on low-carbon tourism traffic behavior intention; (2) there is no significant difference between demographic variables of respondents and most of these factors.
\end{abstract}

\section{Introduction}

The State Council of the PRC "Opinions on speeding up the development of Tourism" clearly pointed out that the promotion of low-carbon tourism, vigorously promote energy saving and emission reduction ${ }^{[1]}$. The Ministry of transport of the PRC "Guidance Opinions on Speed up the development of green low-carbon transportation" integrate the construction of ecological civilization into the transportation development of all aspects and the whole process, speed up the building of a resource-saving and environment-friendly transportation industry, realize green transport development, development cycle, low carbon development. To Wuhan as a tourist city, the development of low-carbon tourism traffic is very necessary ${ }^{[2]}$. In recent years, the research results of low carbon Tourism literature. This paper takes Wuhan residents as research object, the behavior intention concept of low carbon tourism traffic, to explore the low-carbon tourism traffic behavior intention, enrich the research intention, provide a reference for the tourism traffic management departments and enterprises, and promote low-carbon tourism traffic development. In recent years, many research literature on low carbon tourism are emerging. This paper takes Wuhan residents as research object, introduces the concept of behavioral intention to low-carbon tourism traffic research, to explore the low-carbon tourism traffic behavior intention, enrich the research intention, provide a reference for the tourism traffic management departments and enterprises, and promote low-carbon tourism traffic development.

Scuttari, A. (2013) ${ }^{[3]}$ introduces tourism mobility analysis is a tool available to policy-makers when developing integrated and effective sustainable transport and tourism policies. This method is an innovative tourism-traffic analysis based on survey techniques which allows the identification of tourism-related components and an estimate of their environmental impact on a destination.

HOU Yuanxin (2013) ${ }^{[4]}$ analyzes research situation of the self-drive travel abroad, this paper discusses the influence factors of self-driving tourist traffic behavior. DENG Xin-fang (2013) [5] explores under the background of new traffic system, travel preferences and change of tourism consumption patterns, based on the questionnaire survey of self-drive tourists, through factor analysis, variance analysis, independent sample T test. GUAN Hongzhi (2015) ${ }^{[6]}$ established the models of driving behavior in China and Beijing by Logit model, drew the conclusion that income is one of the 
crucial factors, which have influence on the driving demand. WANG Zhao-feng (2014) ${ }^{[7]}$ studies tourists' perception dimensionality, and its impact on tourists' destination satisfaction and behavioral intention in Zhangjiajie city by method of factor analysis. WANG Xiang-zheng (2012) ${ }^{[8]}$ by discrete choice model achieved the characters of tourists were, gave the critical factors affecting traffic mode choice conducted in Beijing Olympic Park. WENG Biyun (2012) ${ }^{[9]}$ examines the characteristics of tourist's choice behavior on travel model of urban tourism peripheral areas in Hangzhou based on the questionnaire survey.

HUANG Xueli (2013) ${ }^{[10]}$ and HU Bing (2014) ${ }^{[11]}$ reveal the driving factors, the formation mechanism and intention characteristics of low-carbon touristic living behaviors based on Theory of Planned Behavior. ZHANG Yan-fei (2013) ${ }^{[12]}$ constructs structural equation model of tourist consumption habits, the consumption environment and the tourist's willingness to participate in low-carbon tourism in the development of low-carbon tourism of natural heritage. LIU Ya-ping (2013) ${ }^{[13]}$ analyzed the differences between two different groups in cognitive degree of low-carbon tourism, willingness and their influencing factors as well as the differences between their willingness and their behavior by adopting logistic function model and crosstabs analysis.

LI Li (2012) ${ }^{[14]}$ introduces the concept of accessibility, and analyzes the influence of urban low-carbon public transport to the accessibility of tourist attractions by means of spacious/time accessibility matrix. LIU Chang-sheng (2012) ${ }^{[15]}$ establishes date enveloping approach (DEA) and stochastic frontier approach (SFA) for the evaluation of "Low-carbon Tourism" service providing efficiency, and makes an empirical analysis on environmental protection and transport service of "Low-carbon Tourism" in Zhangjiajie scenic areas. WU Chen (2012) ${ }^{[16]}$ constructed the scenic area low carbon traffic pattern in term of vehicles site settings, road planning and operations management. LI Bo-hua (2012) ${ }^{[17]}$ and DU Peng (2015) ${ }^{[18]}$ builds calculation model of tourism transportation system carbon footprint, and reveals obvious differences in the structural characteristics of different types of traffic.

This paper reviews and summarizes the research literature of low carbon tourism to build the survey questionnaire of low-carbon tourism traffic behavior and intention influencing factors, and uses the factor analysis, correlation analysis and variance analysis to analyze the behavior attitude, subjective norm, perceived behavioral control and knowledge of low-carbon tourism traffic of Wuhan residents.

\section{Questionnaire Design and Statistics of Demographic Characteristics of the Respondents}

\subsection{Questionnaire Design}

This paper mainly analyze data collection by questionnaire survey. The questionnaire is divided into three parts: personal attribute information, survey of low-carbon tourism traffic behavior, survey of low-carbon tourism traffic behavior intention influencing factors. The first part is investigating the essential information of Wuhan residents. The second and the third part is measuring behavior intention and behavior intention influencing factors of low-carbon tourism for Wuhan residents by scale with Likert 7-point scale method.

Based on mature scale from the existing literature, this paper, with the research purpose, initially formed a questionnaire, and consult relevant experts, deleted and trimmed measurement items of questionnaire scale, and to adjust and optimize the questionnaire, build questionnaire scale for the study, the second part of the scale variables include the behavior attitude, subjective norm, perceived behavioral control and knowledge of low-carbon tourism traffic and tourism traffic consumption concept (Figure 1). 


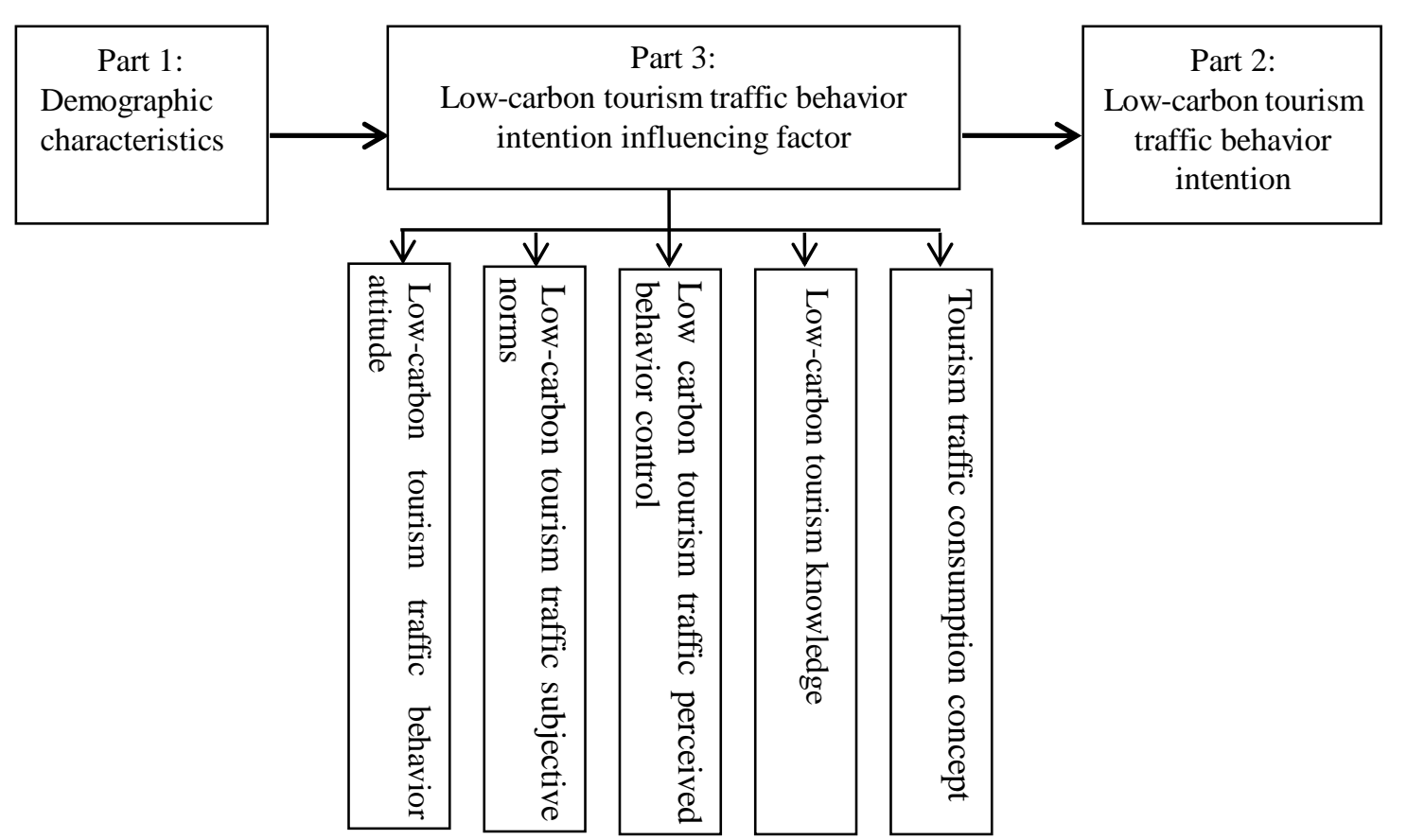

Fig.1 Variable scale structure of low-carbon tourism traffic behavior intention and influencing factor

\subsection{Analysis on Demographic Characteristics of the Respondents}

A total of 150 questionnaires were sent out, and the effective recovery of the questionnaire was 120 , and the effective recovery rate was $80 \%$. Descriptive statistical analysis was used to analyze the demographic characteristics of the respondents, including five basic characteristics of gender, age, education, monthly income, occupation.

Tab.1 The Statistics of Demographic Characteristics of the Respondents

\begin{tabular}{|c|c|c|c|c|c|c|c|}
\hline Item & Type & Number & Percent & Item & Type & Number & Percent \\
\hline \multirow{2}{*}{ Gender } & Male & 66 & 55.0 & \multirow{8}{*}{ Occupation } & Student & 49 & 40.8 \\
\hline & Female & 54 & 45.0 & & Civil servant & 6 & 5.0 \\
\hline \multirow{5}{*}{ Age } & Under 16 years & 4 & 3.3 & & Institution staff & 15 & 12.5 \\
\hline & $16-25$ years & 64 & 53.3 & & $\begin{array}{c}\text { Staff and workers } \\
\text { of enterprise }\end{array}$ & 16 & 13.3 \\
\hline & $26-40$ years & 24 & 20.0 & & Medical Staff & 7 & 5.8 \\
\hline & $41-60$ years & 21 & 17.5 & & Professional & 11 & 9.2 \\
\hline & Above 61 years & 7 & 5.8 & & $\begin{array}{l}\text { Unemployed or } \\
\text { unemployed }\end{array}$ & 9 & 7.5 \\
\hline \multirow{6}{*}{ Education } & Bachelor & 14 & 11.7 & & Others & 7 & 5.8 \\
\hline & Undergraduate & 59 & 49.2 & \multirow{5}{*}{$\begin{array}{l}\text { Monthly } \\
\text { Income }\end{array}$} & No income & 52 & 43.3 \\
\hline & $\begin{array}{l}\text { Junior college } \\
\text { education }\end{array}$ & 17 & 14.2 & & $\begin{array}{c}3000 \text { yuan and } \\
\text { below }\end{array}$ & 17 & 14.2 \\
\hline & High school & 17 & 14.2 & & 3001 - 5000 yuan & 26 & 21.7 \\
\hline & & & & & 5001 - 7000 yuan & 14 & 11.7 \\
\hline & Below high school & 13 & 10.8 & & $\begin{array}{l}7001 \text { yuan and } \\
\text { above }\end{array}$ & 11 & 9.2 \\
\hline
\end{tabular}

Table 1 shows the demographic characteristics of the sample: $55 \%$ of men, $45 \%$ of women; the main research object in 16-60 years Wuhan residents, 16-25 years residents accounted for 53.3\%, 26-40 years residents accounted for 20\%, 41-60 years residents accounted for 17.5\%. Because Wuhan is the largest number of college students in China, the highest proportion of students to participate in the survey accounted for $40.8 \%$; Institution staff and workers of enterprise also accounted for a large part, respectively $12.5 \%$ and $13.3 \%$. Education level of the respondents is mainly above high school, accounting for $89.2 \%$, below high school education level accounted for only about $10.8 \%$. No 
economic income of the respondents accounted for the majority, mainly students.

\section{Reliability analysis of questionnaire scale data}

\subsection{Reliability analysis of scale}

In this paper, the static data is used to test the internal reliability of the scale. Cronbach alpha coefficient is usually used to express the test values of the intrinsic reliability, the higher the value of Cronbach alpha, the higher the reliability. Most scholars agree that the value of Cronbach alpha is greater than 0.7 , and the reliability is very good, the range from 0.5 to 0.7 , the reliability can be accepted, and the value is lower than 0.5 , the reliability refuse to be accepted. In this study, we need to test the reliability of the questionnaire scale.

Tab.2 Reliability analysis of the whole and each variable

\begin{tabular}{lcccccccc}
\hline $\begin{array}{l}\text { Whole and } \\
\text { variable questionnaire }\end{array}$ & $\begin{array}{c}\text { Overall } \\
\text { influence } \\
\text { factors }\end{array}$ & $\begin{array}{c}\text { Behavior Behavior Subjective } \\
\text { intention }\end{array}$ & $\begin{array}{c}\text { Perceived } \\
\text { behavior } \\
\text { control }\end{array}$ & $\begin{array}{c}\text { Tourism } \\
\text { traffic } \\
\text { consumption } \\
\text { concept }\end{array}$ & $\begin{array}{c}\text { Low-carbon } \\
\text { tourism } \\
\text { knowledge }\end{array}$ \\
\hline $\begin{array}{c}\text { Cronbach's } \\
\text { Alpha }\end{array}$ & .924 & .913 & .762 & .852 & .861 & .732 & .802 & .852 \\
$\begin{array}{c}\text { Number of } \\
\text { items }\end{array}$ & 30 & 27 & 3 & 7 & 7 & 6 & 3 & 4 \\
\hline
\end{tabular}

As shown in Table 2, the total items of questionnaire scale is 30 , Cronbach alpha value is 0.924 , of which Low-carbon tourism traffic behavior intention influencing factor scale has 27 items, Cronbach alpha value is 0.913 , Cronbach alpha value of the above both scales are higher than 0.9. Cronbach alpha value of the variables, such as behavioral intention, behavioral attitude, subjective norm, were all the range from 0.7 to 0.9 , which indicated that the reliability of the questionnaire scale was high.

\subsection{Scale validity analysis}

This paper uses factor analysis to verify the construct validity of the questionnaire scale by KMO value and Bartlett spherical test. The purpose of this study is to test whether the questionnaire scale is suitable for factor analysis. The value of KMO is used to test the correlation and partial correlation between scale variables, KMO value more than 0.9 , very suitable for factor analysis; KMO value range from 0.8 to 0.9 , suitable for factor analysis; $\mathrm{KMO}$ value range from 0.8 to 0.7 , generally suitable; $\mathrm{KMO}$ value range from0.6 to 0.7 , minimally suitable for factor analysis; KMO value less than 0.6 , not suitable for factor analysis. The $\mathrm{P}$ value is less than the given significance level, the scale is suitable for factor analysis.

Tab.3 Validity analysis of variable

\begin{tabular}{|c|c|c|c|c|c|c|}
\hline & $\begin{array}{l}\text { Behavior } \\
\text { intention }\end{array}$ & $\begin{array}{l}\text { Behavior } \\
\text { attitude }\end{array}$ & $\begin{array}{l}\text { Subjective } \\
\text { norms }\end{array}$ & $\begin{array}{c}\text { Perceived } \\
\text { behavior } \\
\text { control }\end{array}$ & $\begin{array}{c}\text { Tourism } \\
\text { traffic } \\
\text { consumption } \\
\text { concept }\end{array}$ & $\begin{array}{c}\text { Low-carbon } \\
\text { tourism } \\
\text { knowledge }\end{array}$ \\
\hline $\begin{array}{c}\text { Kaiser-Meyer-Olkin Measure } \\
\text { of Sampling Adequacy. }\end{array}$ & .738 & .791 & .840 & .775 & .706 & .728 \\
\hline Bartlett's Approx. Chi-Square & 93.130 & 399.053 & 403.412 & 133.390 & 114.017 & 236.495 \\
\hline Test of & 3 & 21 & 21 & 15 & 3 & 6 \\
\hline Sphericity & .000 & .000 & .000 & .000 & .000 & .000 \\
\hline
\end{tabular}

As shown in Table 3, KMO value of low-carbon tourism traffic behavior intention scale is 0.738 , and $\mathrm{KMO}$ values of 5 variable scales of low-carbon tourism traffic behavior intention influencing factor are greater than 0.7 . Sig. of 6 variables the questionnaire scale of scale is 0.000 , which shows there is a correlation between measurable variables of low-carbon tourism traffic behavior intention and influencing factors of it, both are suitable for factor analysis.

\subsection{Scale factor analysis}

In this paper, the exploratory factor analysis was used for the variables of questionnaire scale, the 
principal component analysis method was used to extract the factors, and the maximum variance rotation method is selected to perform orthogonal rotation. Based on the principle that the eigenvalue greater than 1 is extracted, 6 factors is obtained. According to the factor load split items after the different items processed in the orthogonal rotation, and then the precipitation factor will be named. The above shown in table 4.

Tab.4 Factor analysis results

\begin{tabular}{|c|c|c|c|c|c|}
\hline Extraction Factor & Item & $\begin{array}{l}\text { Factor } \\
\text { loading }\end{array}$ & Initial Eigenvalues & $\begin{array}{c}\text { Variance } \\
\text { Contribution } \\
\end{array}$ & $\begin{array}{c}\text { Cumulative } \\
\text { Explained }\end{array}$ \\
\hline \multirow{3}{*}{ Behavior intention } & B2.1 & .862 & \multirow{3}{*}{2.048} & \multirow{3}{*}{68.280} & \multirow{3}{*}{68.280} \\
\hline & B2.2 & .821 & & & \\
\hline & $\mathrm{B} 2.3$ & .795 & & & \\
\hline \multirow{7}{*}{ Behavior attitude } & $\mathrm{A} 2.1$ & .826 & \multirow{7}{*}{3.777} & \multirow{7}{*}{53.952} & \multirow{7}{*}{53.952} \\
\hline & A 2.2 & .821 & & & \\
\hline & A2.3 & .778 & & & \\
\hline & A2.4 & .749 & & & \\
\hline & $\mathrm{A} 2.5$ & .699 & & & \\
\hline & A2.6 & .643 & & & \\
\hline & A2.7 & .592 & & & \\
\hline \multirow{7}{*}{ Subjective norms } & $\mathrm{R} 2.1$ & .868 & \multirow{7}{*}{3.975} & \multirow{7}{*}{56.781} & \multirow{7}{*}{56.781} \\
\hline & $\mathrm{R} 2.2$ & .838 & & & \\
\hline & $\mathrm{R} 2.3$ & .807 & & & \\
\hline & $\mathrm{R} 2.4$ & .772 & & & \\
\hline & $\mathrm{R} 2.5$ & .760 & & & \\
\hline & $\mathrm{R} 2.6$ & .689 & & & \\
\hline & $\mathrm{R} 2.7$ & .469 & & & \\
\hline \multirow{6}{*}{ Perceived behavior control } & $\mathrm{C} 2.1$ & .733 & \multirow{6}{*}{2.600} & \multirow{6}{*}{43.339} & \multirow{6}{*}{43.339} \\
\hline & $\mathrm{C} 2.2$ & .714 & & & \\
\hline & $\mathrm{C} 2.3$ & .691 & & & \\
\hline & $\mathrm{C} 2.4$ & .675 & & & \\
\hline & $\mathrm{C} 2.5$ & .562 & & & \\
\hline & $\mathrm{C} 2.6$ & .551 & & & \\
\hline \multirow{3}{*}{$\begin{array}{l}\text { Tourism traffic consumption } \\
\text { concept }\end{array}$} & S2.1 & .868 & \multirow{3}{*}{2.156} & \multirow{3}{*}{71.864} & \multirow{3}{*}{71.864} \\
\hline & $\mathrm{S} 2.2$ & .851 & & & \\
\hline & $\mathrm{S} 2.3$ & .823 & & & \\
\hline \multirow{4}{*}{$\begin{array}{l}\text { Low-carbon tourism } \\
\text { knowledge }\end{array}$} & $\mathrm{T} 2.1$ & .863 & \multirow{4}{*}{2.782} & \multirow{4}{*}{69.556} & \multirow{4}{*}{69.556} \\
\hline & $\mathrm{T} 2.2$ & .850 & & & \\
\hline & $\mathrm{T} 2.3$ & .841 & & & \\
\hline & $\mathrm{T} 2.4$ & .780 & & & \\
\hline
\end{tabular}

\section{Correlation analysis and variance analysis of scale data}

\subsection{Correlation analysis}

In this paper, the 30 interrelationship items reduce to 6 factors by factor analysis, then analyze the relevance between the 6 factors and low-carbon tourism traffic behavior intention by Pearson simple correlation analysis method. 
Tab.5 Correlation analysis of influencing factors

\begin{tabular}{|c|c|c|c|c|c|c|c|}
\hline & & $\begin{array}{l}\text { Behavior } \\
\text { intention }\end{array}$ & $\begin{array}{l}\text { Behavior } \\
\text { attitude }\end{array}$ & $\begin{array}{c}\text { Subjective } \\
\text { norms }\end{array}$ & $\begin{array}{c}\text { Perceived } \\
\text { behavior } \\
\text { control }\end{array}$ & $\begin{array}{l}\text { Tourism traffic } \\
\text { consumption } \\
\text { concept }\end{array}$ & $\begin{array}{l}\text { Low-carbon } \\
\text { tourism } \\
\text { knowledge }\end{array}$ \\
\hline \multirow{2}{*}{$\begin{array}{l}\text { Behavior } \\
\text { intention }\end{array}$} & $\begin{array}{c}\text { Pearson } \\
\text { Correlation }\end{array}$ & 1 & $.804 * *$ & $.773 * *$ & $.521 * *$ & -0.049 & $.432 * *$ \\
\hline & $\begin{array}{c}\text { Sig. } \\
\text { 2-tailed) }\end{array}$ & & 0 & 0 & 0 & 0.597 & 0 \\
\hline \multirow{2}{*}{$\begin{array}{l}\text { Behavior } \\
\text { attitude }\end{array}$} & $\begin{array}{l}\text { Pearson } \\
\text { Correlation }\end{array}$ & $.804 * *$ & 1 & $.827 * *$ & $.524 * *$ & -0.056 & $.357 * *$ \\
\hline & $\begin{array}{c}\text { Sig. } \\
\text { 2-tailed) }\end{array}$ & 0 & & 0 & 0 & 0.545 & 0 \\
\hline \multirow{2}{*}{$\begin{array}{l}\text { Subjective } \\
\text { norms }\end{array}$} & $\begin{array}{l}\text { Pearson } \\
\text { Correlation }\end{array}$ & $.773 * *$ & $.827 * *$ & 1 & $.659 * *$ & 0.077 & $.401 * *$ \\
\hline & $\begin{array}{c}\text { Sig. } \\
\text { 2-tailed) }\end{array}$ & 0 & 0 & & 0 & 0.404 & 0 \\
\hline \multirow{2}{*}{$\begin{array}{l}\text { Perceived } \\
\text { behavior } \\
\text { control }\end{array}$} & $\begin{array}{l}\text { Pearson } \\
\text { Correlation }\end{array}$ & $.521 * *$ & $.524 * *$ & $.659 * *$ & 1 & $.307 * *$ & $.531 * *$ \\
\hline & $\begin{array}{c}\text { Sig. } \\
\text { 2-tailed) }\end{array}$ & 0 & 0 & 0 & & 0.001 & 0 \\
\hline \multirow{2}{*}{$\begin{array}{l}\text { Tourism traffic } \\
\text { consumption } \\
\text { concept }\end{array}$} & $\begin{array}{c}\text { Pearson } \\
\text { Correlation }\end{array}$ & -0.049 & -0.056 & 0.077 & $.307 * *$ & 1 & $.236^{* *}$ \\
\hline & $\begin{array}{c}\text { Sig. } \\
\text { 2-tailed) }\end{array}$ & 0.597 & 0.545 & 0.404 & 0.001 & & 0.01 \\
\hline $\begin{array}{l}\text { Low-carbon } \\
\text { tourism }\end{array}$ & $\begin{array}{c}\text { Pearson } \\
\text { Correlation }\end{array}$ & $.432 * *$ & $.357 * *$ & $.401 * *$ & $.531 * *$ & $.236 * *$ & 1 \\
\hline knowledge & $\begin{array}{c}\text { Sig. } \\
\text { 2-tailed) }\end{array}$ & 0 & 0 & 0 & 0 & 0.01 & \\
\hline
\end{tabular}

**. Correlation is significant at the .01 level (2-tailed).

Table 5 shows that the value of Pearson correlation coefficient between low-carbon tourism traffic behavior intention and one of the four including low-carbon tourism traffic behavior attitude, subjective norm, perceived behavior control and knowledge respectively were $0.804,0.773,0.332$. Sig. is 0.000 less than 0.01 , which express significantly at the 0.01 level. Correlation between low-carbon tourism traffic behavior intention and one of the four including low-carbon tourism traffic behavior attitude, subjective norm, perceived behavior control and knowledge is significant at the 0.01 level.

However, the Pearson correlation coefficient between low-carbon tourism traffic behavioral intention and tourism traffic consumption concept is -0.049 , which indicates that there is a negative correlation between them. Sig. is 0.597 greater than 0.05 , which shows that correlation between them is not significant at the 0.05 level.

\subsection{Variance analysis}

One-factor analysis of variance was used to test $\mathrm{F}$, and then according to the significance coefficient of the $\mathrm{F}$ value of to determine the degree of the impact of the age, education, monthly income and occupation on the factors.

From table 6, different education respondents on low-carbon tourism traffic behavior intention and behavior attitude exists significant difference, different occupation respondents on low-carbon tourism traffic behavior attitude, subjective norm, perceived behavior control and knowledge exists significant difference, the same to different monthly income on low-carbon tourism traffic behavior attitude and knowledge. The Sig. of the F value for most of the other demographic variables on each factor was greater than 0.05 , indicating that demographic variables of the majority of respondents have no 
significant impact on each factor.

Tab.6 One-factor analysis of variance

\begin{tabular}{|c|c|c|c|c|c|c|c|c|c|c|}
\hline \multirow{2}{*}{$\begin{array}{l}\text { Measurement } \\
\text { factors }\end{array}$} & \multicolumn{5}{|c|}{$\mathrm{F}$} & \multicolumn{5}{|c|}{ Sig. } \\
\hline & Gender & Age & Education & Occupation & $\begin{array}{l}\text { Monthly } \\
\text { Income }\end{array}$ & Gende & r Age l & ducation & Occupation & $\begin{array}{l}\text { Monthly } \\
\text { Income }\end{array}$ \\
\hline $\begin{array}{l}\text { Behavior } \\
\text { intention }\end{array}$ & .907 & .931 & 1.195 & 1.071 & 1.198 & .645 & .607 & .024 & .395 & .243 \\
\hline $\begin{array}{l}\text { Behavior } \\
\text { attitude }\end{array}$ & .794 & .698 & 1.306 & 1.635 & 2.395 & .723 & .801 & .038 & .255 & .041 \\
\hline $\begin{array}{l}\text { Subjective } \\
\text { norms }\end{array}$ & .998 & .485 & 1.131 & 2.227 & 1.506 & .630 & .868 & .584 & .031 & .483 \\
\hline $\begin{array}{l}\text { Perceived } \\
\text { behavior } \\
\text { control }\end{array}$ & .585 & .842 & 1.095 & 2.327 & .859 & .847 & .680 & .541 & .003 & .669 \\
\hline $\begin{array}{c}\text { Tourism } \\
\text { traffic } \\
\text { consumption } \\
\text { concept }\end{array}$ & 1.081 & .951 & .728 & 1.113 & .903 & .389 & .582 & .889 & .348 & .657 \\
\hline $\begin{array}{c}\text { Low-carbon } \\
\text { tourism } \\
\text { knowledge }\end{array}$ & 1.475 & 1.276 & .944 & 2.162 & 1.599 & .093 & .205 & .595 & .005 & .055 \\
\hline
\end{tabular}

\section{Conclusion}

This paper makes an empirical study on the relationship among low-carbon tourism traffic behavior attitude, subjective norm, perceived behavior control and knowledge, tourism traffic consumption concept and low-carbon tourism traffic behavior intention, and obtained low-carbon tourism traffic behavior attitude, subjective norm, perceived behavior control and knowledge, tourism traffic consumption concept, tourist traffic consumption is how to influence low-carbon tourism traffic behavior intention.

Low-carbon tourism traffic behavior attitude, subjective norm, perceived behavior control have the biggest positive impact on low-carbon tourism traffic behavior intention. If the higher and the positive evaluation of tourism traffic low-carbon behavior, the more correct understanding of the moral standard, the more confident in their ability to travel, the stronger cognition, low-carbon tourism traffic behavior intention tourists follows is greater.

From the aspects of gender, age, education, income and occupation, by investigating the relationship among demographic variables of respondents, low-carbon tourism traffic behavior intention and influencing factors of that, there is no significant difference between demographic variables of respondents and most of these factors.

\section{Acknowledgments}

The authors acknowledge the research grants from Humanities and social Scientific Researchh Guidance Project for Hubei Provincial Department of Education (14G467).

Corresponding author: LIU Chun, Wuhan Technology and Business University, Department of Management, Wuhan 430065, CHINA

\section{References}

[1] The State Council of the PRC. Opinions on speeding up the development of Tourism [EB/OL]. http://www.gov.cn/xxgk/pub/govpublic/mrlm/200912/t20091203_56294.html, 2009-12-01/2017-03-22. 
[2] The Ministry of transport of the PRC. Guidance Opinions on Speed up the development of green low-carbon transportation [EB/OL]. http://www.gov.cn/gongbao/content/2013/content_2466586.htm, 2013-05-22/2017-03-22.

[3] Scuttari, A., Della Lucia, M., Martini, U. Integrated planning for sustainable tourism and mobility. A tourism traffic analysis in Italy's South Tyrol region [J]. Journal of Sustainable Tourism, 2013, 21(4): 614-637.

[4] HOU Yuanxin, WANG Jia. Analysis of traffic behavior of self-driving tourism [J]. Tourism survey, 2013 (7): 17.

[5] DENG Xin-fang, SHAO Ling. Study of Behavior Characteristics of Self-driving Tourists under New Traffic System: Based on Investigation of Xinjiang Tourists [J]. Value engineering, 2013(28): 152-154.

[6] GUAN Hongzhi, SHAO Jie, LI Yaru, BAI Hongling. A Travel Behavior Model for sightseeing Travel [J]. Urban transport of China, 2015, 3(4): 59-62.

[7] WANG Zhaofeng. Tourists' perception of urban public transport, satisfaction and behavioral intention in Zhangjiajie city, China [J]. Geographical Research, 2014,33(5): 978-987.

[8] WANG Xiang-zheng, GONG Xiao-gang. Research on Tourism Traffic Mode Choice [J]. Transportation standardization, 2012(9): 83-86.

[9] WENG Biyun, BIAN Xianhong. Analysis on Tourist's Choice Behavior on Travel Mode: A Case of Urban Tourism Peripheral Areas in Hangzhou [J]. Jiangsu Commercial Forum, 2012(3): 115-117.

[10] HUANG Xueli, LU Zhengnan, Yasong (Alex) WANG. Study on Construetion Analysis Model of Influencing Factors of Low-carbon Touristic Living Behaviors Based on TPB and VBN [J]. Science Technology Management Research, 2013, (21):181-190.

[11] HU Bing, FU Yun-xin, XIONG Yuan-bin. The Driving Factors and the Formation Mechanism of Tourists' Intention Participating in Low-carbon Tourism: Based on Theory of Planned Behavior [J]. Journal Of Business Economics, 2014, (8):64-72.

[12] ZHANG Yan-fei, ZHU Hai-ying, LIU Fang. Relationship on Tourism Environments, Consumption Habits and Participation Willingness of Low-carbon Tourism: Taking the Wulingyuan Natural Heritage Site as an Example [J]. Tourism Tribune, 2013, 28(6): 56-64.

[13] LIU Ya-ping, LIU Qing. Behavioral Difference Analysis On Cognition And Willingness On Low-Carbon Tourism: Based On The Case Of The Two Groups In Nanning [J]. Human Geography, 2013, 28(4): 132-139.

[14] LI Li, WANG De-gen. The Impact of Urban Low- Carbon Public Transport to Tourist Attractions' Accessibility — Suzhou City Area as the Example [J]. Economic Geography, 2012, 32(3): 166-172.

[15] LIU Chang-sheng. On the Evaluation Approach of "Low-carbon Tourism" Service Providing Efficiency and Its Empirical Study Based on the Empirical Inspection of Environmental Protection and Transport Tourism Service in Zhangjiajie [J]. Tourism Tribune, 2012, 27(3): 90-98.

[16] WU Chen, LI Dons- he, WANG Yan. Study of Low Carbon Traffic Pattern in Tourism Scenic Area [J]. Resource Development \& Market, 2012, 28(8): 747-750.

[17] LI Bo-hua, LIU Yun-peng, DOU Yin-di. Carbon Footprint Evaluation of Tourism Transportation System in Tourist Attractions and Analysis of the Influencing Factors: A Case Study in Hengshan [J]. Resources Science, 2012, 34(5): 956-963.

[18] DU Peng, YANG Lei. The Research on the Carbon Footprint of Tourism Transport and the Strategy Analysis for Low Carbon Travel [J]. Ecological Economy, 2015, 31(2): 59-63. 